\title{
UAB
}

Universitat Autònoma

de Barcelona

This is the accepted version of the article:

Palacín Lizarbe, Carlos; Camarero, Lluís; Catalan, Jordi. Denitrification temperature dependence in remote, cold, and N-poor lake sediments. DOI 10.1002/2017WR021680

This version is avaible at https://ddd.uab.cat/record/203571

under the terms of the C) ${ }_{\text {COPYRIGHT license }}^{\mathbb{N}}$ 


\section{Denitrification temperature dependence in remote, cold and N-poor lake sediments}

Carlos Palacin-Lizarbe ${ }^{1,2}$ (orcid.org/0000-0002-1572-6053), Lluís Camarero² (orcid.org/0000-0003-4271-8988) (D), and Jordi Catalan ${ }^{1,3}$ (orcid.org/0000-0002-2934-4013) (1)

${ }^{1}$ CREAF, Campus UAB, Edifici C, E-08193 Cerdanyola del Vallès, Spain, ${ }^{2}$ Center for Advanced Studies of Blanes, (CEAB-CSIC), C/ d'accés a la Cala St. Francesc 14, E-17300 Blanes, Girona, Spain, ${ }^{3}$ CSIC, E-08193 Cerdanyola del Vallès, Spain

Correspondence to: C. Palacin-Lizarbe (cpalacli7@gmail.com)

\section{Key Points:}

- Denitrification rates in mountain lakes are both nitrate and temperature limited.

- The apparent activation energy $\left(\mathrm{E}_{\mathrm{a}}, \mathrm{kJ} \mathrm{mol}^{-1}\right)$ for denitrification depends on nitrate $(\mu \mathrm{M})$ as $\mathrm{E}_{\mathrm{a}}=46+419\left[\mathrm{NO}_{3}^{-}\right]^{-1}$.

- The impact of nitrogen emission reductions on the adjustment of the nitrogen cycle may be enhanced by climate warming.

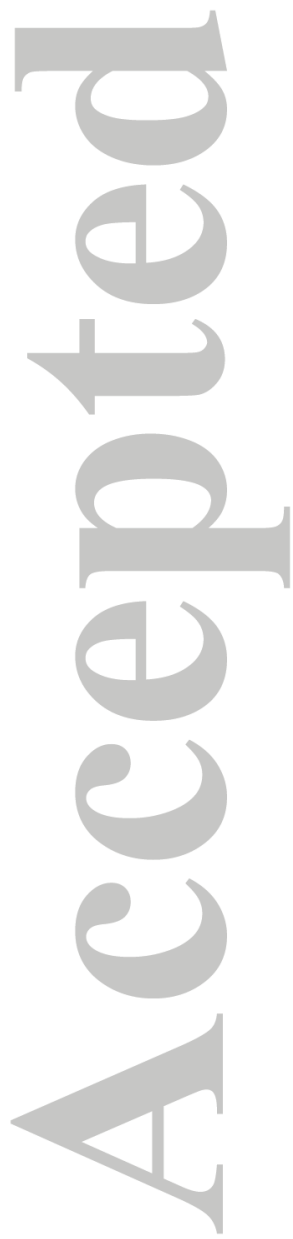

This article has been accepted for publication and undergone full peer review but has not been through the copyediting, typesetting, pagination and proofreading process which may lead to differences between this version and the Version of Record. Please cite this article as an 'Accepted Article', doi: 10.1002/2017WR 021680 


\section{Abstract}

The reservoir size and pathway rates of the nitrogen $(\mathrm{N})$ cycle have been deeply modified by the human enhancement of $\mathrm{N}$ fixation, atmospheric emissions, and climate warming. Denitrification (DEN) transforms nitrate into nitrogenous gas and thus removes reactive nitrogen $\left(\mathrm{N}_{\mathrm{r}}\right)$ back to the atmospheric reservoir. There is still a rather limited knowledge of the denitrification rates and their temperature dependence across ecosystems; particularly, for the abundant cold and N-poor freshwater systems (e.g., Arctic and mountain lakes). We experimentally investigated the denitrification rates of mountain lake sediments by manipulating nitrate concentration and temperature on field collected cores. DEN rates were nitrate limited in field conditions and showed a large potential for an immediate DEN increase with both warming and higher $\mathrm{N}_{\mathrm{r}}$ load. The estimated activation energy $\left(E_{\mathrm{a}}\right)$ for denitrification at nitrate saturation was $46 \pm 7 \mathrm{~kJ} \mathrm{~mol}^{-1}$ $\left(\mathrm{Q}_{10}\right.$ 1.7 \pm 0.4$)$. The apparent $\mathrm{E}_{\mathrm{a}}$ increased with nitrate $(\mu \mathrm{M})$ limitation as $\mathrm{E}_{\mathrm{a}}=46+419\left[\mathrm{NO}_{3}\right]^{-1}$. Accordingly, we suggest that climate warming may have a synergistic effect with $\mathrm{N}$ emission reduction to readjusting the $\mathrm{N}$ cycle. Changes of nitrate availability might be more relevant than direct temperature effects on denitrification.

\section{Introduction}

The anthropogenic alteration of the nitrogen $(\mathrm{N})$ cycle is one of the most challenging problems for the Earth system [Rockstrom et al., 2009]. Human activity has at least doubled the levels of reactive nitrogen $\left(\mathrm{N}_{\mathrm{r}}\right)$ available to the biosphere, largely as a result of the industrial $\mathrm{N}$ fixation for fertilizer productions and the burning of fossil fuels [Erisman et al., 2011]. The global $\mathrm{N}$ cycle is still evaluated with high uncertainty. A few flux estimates are quantified with less than $\pm 20 \%$ error and many have uncertainties of $\pm 50 \%$ and larger [Gruber and Galloway, 2008]. The transient situation of the planet with many factors that influence the $\mathrm{N}$ cycle changing simultaneously, demands a deeper understanding of the factors controlling the rates of the $\mathrm{N}$ cycle pathways [Baron et al., 2013; Greaver et al., 2016]. The temperature dependence of the rates of the distinct pathways is of particular interest for evaluating potential synergistic effects of climate warming and nitrogen emissions on $\mathrm{N}$ global cycle.

Denitrification (DEN) is the microbial activity by which nitrogenous oxides, mainly nitrate and nitrite, are reduced to dinitrogen gasses, $\mathrm{N}_{2} \mathrm{O}$ and $\mathrm{N}_{2}$ [Tiedje, 1988]. DEN is the primary process removing $\mathrm{N}_{\mathrm{r}}$ from the biosphere [Seitzinger et al., 2006]. The DEN dynamics is typically episodic; driven by the fluctuating coexistence of primary resources, favorable conditions, and the microbial agents. Consequently, DEN rates are difficult to measure, model and upscale. Existing methods are problematic for different reasons [Groffman et al., 2006]. Much of the challenges arise from the fact that small areas (hot spots) and brief periods (hot moments) account for a high percentage of the denitrification activity both in terrestrial and aquatic ecosystems [Parkin, 1987; McClain et al., 2003; Groffman et al., 2009]. A substantial proportion of denitrification occurs in the upper part of the sediments, where necessary resources (e.g. Noxides, fresh organic matter) meet anaerobic conditions. Lakes have been identified as the aquatic ecosystems with the highest seasonal and site variation in DEN rates [Piñ-Ochoa and Alvarez-Cobelas, 2006], although part of the observed variability could be due to the methods applied. Particularly, the alteration of the integrity of the samples markedly affects the DEN rate $\left(\mathrm{r}_{\mathrm{d}}\right)$ measured. Higher values in slurries are obtained compared to undisturbed core sediments [Ambus, 1993]. The former cannot be considered representing in situ rates. They only provide relative measures for comparisons, if applied in the same way. However, if the target is to integrate DEN rates in the evaluation of the nitrogen cycle, there is an urgent demand of 
measurements in conditions as close as possible to the natural ones to reduce the uncertainty of the estimates and provide the elements for a reliable upscaling of the measurements [Galloway, 2004; Gruber and Galloway, 2008].

The temperature dependence of an enzymatic process can be described by its activation energy $\left(\mathrm{E}_{\mathrm{a}}\right)$, which reflects the increase in the rate with temperature [Arrhenius, 1915] when there is no resource limitation. However, the biogeochemical $\mathrm{E}_{\mathrm{a}}$ includes also temperature effects on molecular kinetics, physiological acclimation by microbial strains and microbial assemblage changes [Hall et al., 2010; Crowther and Bradford, 2013]. In natural conditions, the $\mathrm{E}_{\mathrm{a}}$ values reflect a multi-step process and thus can vary with the substrate availability [Brezonik, 1994] and may depend on the particular assemblage of organisms performing the biogeochemical reaction [Hall et al., 2008]. Each of these DEN control levels has a longer characteristic time, from instantaneous to a few days.

In lakes, sediment DEN rates at timescales below a few days are more likely to be constrained by the substrate supply than temperature fluctuations. Nitrate declines by the same DEN activity and their supply depend on other microbial activities (e.g., nitrification) and physical transport. When measuring $\mathrm{DEN} \mathrm{E}_{\mathrm{a}}$, experimentally, some environmental conditions may depart easily from those in situ, either because of the use of an unrealistic temperature range [Boulêtreau et al., 2012], very high nitrate addition [Holmes et al., 1996] or both. Alternatively, some observational approaches to estimate DEN $E_{a}$ use activities $\left(r_{d}\right)$ measured at periods of the year with contrasting temperature [Bachand and Horne, 2000; Sheibley et al., 2003]. In this case, the substrate availability may change but also the assemblage of microorganisms present.

Consequently, there are a number of aspects to consider in an assessment of the biogeochemical DEN $E_{a}$ for a certain type of ecosystems (Fig. 1). They include 1) the general methodological approach; fundamentally, whether the approach is experimental, controlling the temperature change, or observational, using spatial or temporal natural temperature variation. 2) How the substrates (i.e., organic carbon, nitrogen) are considered; particularly, whether they are artificially saturated or maintained within natural conditions. And, 3) which are the biogeochemical processes that could be a source of added uncertainty in the assessment provided their competition for nitrate or nitrite or their release of nitrous oxide.

There are few studies of the DEN $\mathrm{E}_{\mathrm{a}}$ in oligotrophic systems [Holmes et al., 1996] and most are marine [Rysgaard et al., 2004; Canion et al., 2014a]. In the current situation of global change, the case of remote ecosystems, those that are mostly influenced by atmospheric processes rather than direct human action in the watershed, are of particular interest. Many of these sites (e.g., alpine and subarctic regions) have, are or would experience increased $\mathrm{N}_{\mathrm{r}}$ deposition [Holtgrieve et al., 2011] and warming [Smol, 2012]. Therefore, they are key sites for studying the interaction between temperature and the $\mathrm{N}$ cycle [Catalan et al., 2013].

The increase of $\mathrm{N}_{\mathrm{r}}$ deposition is eventually reflected in the stream and lake loads depending on the degree of $\mathrm{N}$ saturation in the soil and vegetation [Stoddard, 1994]. Long-term sustained high $\mathrm{N}_{\mathrm{r}}$ deposition results in a watershed quasi-steady-state so that $\mathrm{N}_{\mathrm{r}}$ deposition and streams show similar temporal trends and fluctuations. One may expect that lakes would follow streams midterm temporal patterns. However, recently, Camarero and Catalan [2012] have found an opposite trend during the last decades in the Pyrenees between lakes and streams. The latter follows the still $\mathrm{N}_{\mathrm{r}}$ increasing tendency in the deposition, but lakes show a decline. The authors have attributed the opposed trends to an increase in lake productivity related to a higher phosphorus deposition. However, they were not able to evaluate whether an enhancement of denitrification could be an alternative explanation due to the lack of empirical information. The 
difficulty of the measuring DEN rates at low $\mathrm{N}_{\mathrm{r}}$ concentrations may justify why remote systems have been overlooked with a few exceptions [McCrackin and Elser, 2010; 2012; Vila-Costa et al., 2016; Castellano-Hinojosa et al., 2017]. Indeed, it has been only one attempt to estimate DEN $E_{\mathrm{a}}$ in these systems [Myrstener et al., 2016]. Consequently with this gap in knowledge, the aim of this study was to assess the DEN temperature dependence $\left(E_{a}\right)$ in remote, cold and relatively N-poor lakes. From the several options above introduced (Fig. 1), our approach was thought as one that could be useful for an evaluation of the actual in situ rates in the area studied, the potential upscaling of DEN estimations over large sets of oligotrophic lakes, and projections of future scenarios of air temperature and nitrate deposition. Therefore, DEN measurements were conducted using intact core sediments, the acetylene inhibition method combined with sensors for nitrous oxide and experimental control of temperature and nitrate availability within the natural range found in these lakes. For complementarity, we compiled the existing data on DEN temperature dependence in aquatic ecosystems across the literature and evaluated the results according to the framework introduced in Fig. 1, emphasizing the likely reasons for the large variation in the estimations and, if so, the discrepancies with our results.

\section{Materials and Methods}

\subsection{General methodological approach}

Three lakes with contrasting morphology and carbon flow characteristics (Table 1) were sampled to consider potential different microbial communities. In each sampling date, we collected five core sediments in the field, which were immediately transported to the lab to control for temperature and nitrate availability within the ranges that can be found in these mountain lakes. We used sensors for nitrous oxide combined with the acetylene inhibition method and anoxic conditions to minimize the disturbance of the sediment structure. For each core, we performed sequential estimations of the DEN rates $\left(r_{d}\right)$ at several temperature values and nitrate concentrations. This procedure reduces the noise that the sediment spatial heterogeneity can introduce in the estimations but may introduce autocorrelation effects. To overcome the latter constraint, we did not follow the same experimental sequence in each trial, so we could statistically evaluate the autocorrelation influence and distinguish it from other sources of variation (e.g., nitrate concentration, lake, sensors). Although the experiment was planned for the same number of cores per lake (5), finally, we also included in the data set two preliminary tests - performed using only a part of the nitrate gradient in some Lake Redon cores - as they fitted in the general results obtained and thus increased the statistical robustness of the final model.

\subsection{Sampling and experimental design}

The selected three lakes are representative of the lake district of the Pyrenees (Table 1). They cover a broad range of maximum depth $(9-73 \mathrm{~m})$ and seasonal thermal variability [Catalan et al., 2002]. The experimental temperature $\left(5-15^{\circ} \mathrm{C}\right)$ and the nitrate added levels $(7-14-28 \mu \mathrm{M})$ covered the natural variability in the region and possible future scenarios. A total of 25 sediment cores (methacrylate, ø $6.35 \mathrm{~cm}$ ) were assessed (15 from Redon, 5 from Plan and 5 from Llong, Table S1). They were collected with a gravity corer [Glew, 1991] at midday around the deepest point of each lake (Table 1). Only undisturbed cores with clear overlying water and interface were used. The experimental setup included an incubation chamber that ensured dark conditions and controlled temperature $\left( \pm 1^{\circ} \mathrm{C}\right.$ ) (Fig. 2). Nitrate was measured at the beginning of the

incubations (Table S1). As a precautionary action, glucose was added in excess $\left(1.5 \mathrm{~g} \mathrm{~L}^{-1}\right)$ to 
avoid carbon limitation [Vila-Costa et al., 2016] despite that some previous tests did not show conclusive evidence of such limitation. DEN measurements at different nitrate concentrations and temperatures started the next morning and were conducted sequentially, commonly: Step 1: First $7 \mu \mathrm{M}$ nitrate addition at $5^{\circ} \mathrm{C}(0-12 \mathrm{~h}) ; 2$ : $15^{\circ} \mathrm{C}(12-24 \mathrm{~h}) ; 3$ : Second $7 \mu \mathrm{M}$ nitrate addition at $15^{\circ} \mathrm{C}(24-36 \mathrm{~h}) ; 4: 5^{\circ} \mathrm{C}(36-48 \mathrm{~h}) .5: 14 \mu \mathrm{M}$ nitrate addition at $5^{\circ} \mathrm{C}(48-60 \mathrm{~h})$; and $6: 15^{\circ} \mathrm{C}(60$ $72 \mathrm{~h})$.

\subsection{Denitrification measurement}

DEN measurements were performed using the acetylene inhibition method combined with sensors for nitrous oxide $\left(\mathrm{N}_{2} \mathrm{O}\right)$. Anoxia, first, and acetylene inhibition, after, were achieved by bubbling $\mathrm{N}_{2}$ and $\mathrm{C}_{2} \mathrm{H}_{2}$ sequentially, respectively, during 10 minutes in the water phase of the core before each DEN measurement. Acetylene inhibits the reduction of $\mathrm{N}_{2} \mathrm{O}$ to $\mathrm{N}_{2}$ [Balderston et al., 1976; Yoshinari and Knowles, 1976]. The accumulated $\mathrm{N}_{2} \mathrm{O}$ was measured using a modified Clark electrode probe $\left(\mathrm{N}_{2} \mathrm{O}-\mathrm{R}\right.$ microsensor, Unisense $\mathrm{A} / \mathrm{S}$, Denmark) (detection limit $=$ $0.1 \mu \mathrm{M})$, in the water phase. A gentle magnet stirring was applied to avoid stratification but without resuspension of the sediment. Readings were taken every 5 minutes via a picoammeter logged to a laptop. The response of the electrochemical sensor is linear in the range of $0-1.2 \mathrm{mM}$ [Andersen et al., 2001]. The instrument was kept polarized during all the measurement period. It was calibrated at each temperature using a calibration chamber (CAL300, Unisense A/S, Denmark), zero gas water (Milli-Q) and a freshly prepared $\sim 50 \mu \mathrm{M} \mathrm{N}_{2} \mathrm{O}$ solution. The latter was obtained adding a certain volume of $\mathrm{N}_{2} \mathrm{O}$ saturated water [Weiss and Price, 1980] to the zero gas water following manufacturer's instructions as described in Foley et al. [2010].

\subsection{Water and sediment characterization}

Immediately after collection, we measured the temperature $\left({ }^{\circ} \mathrm{C}\right)$ of water overlying the sediment core (Table 1). For chemical analyses, water samples were filtered through a pre-combusted $(4 \mathrm{~h}$ at $\left.450^{\circ} \mathrm{C}\right) \mathrm{GF} / \mathrm{F}$ glass fiber filter. Nitrate was determined by capillary electrophoresis using a Quanta 4000 (Waters) instrument. Ammonium and nitrite were determined by colorimetric methods in a segmented-flow autoanalyzer (AA3HR, Seal), using the Berthelot reaction for ammonium (Bran+Luebbe method G-171-96) and the Griess reaction for nitrite (Bran+Luebbe method G-173-96). Dissolved organic carbon (DOC) was measured by catalytic combustion to $\mathrm{CO}_{2}$ and detection by IR spectroscopy in a TOC5000 (Shimadzu) analyzer. The water column of the lakes sampled show a circumneutral pH ( 7) [Vila-Costa et al., 2014].

After DEN measurements, the surface sediment was sliced $(2 \mathrm{~cm})$ and freeze-dried for $72 \mathrm{~h}$. Around $5 \mathrm{mg}$ of the dried sample was encapsulated together with a catalyst $\left(\mathrm{Va}_{2} \mathrm{O}_{5}\right)$ in tin capsules for the determination of $\mathrm{C}$ and $\mathrm{N}$ using a $\mathrm{C}-\mathrm{H}-\mathrm{N}-\mathrm{S}$ (Carlo-Erba) analyzer. The dry weight percentage of organic matter content in the sediments was determined by loss on ignition (LOI) following Heiri et al. [2001]. In all cases, the samples were equilibrated to room temperature in a desiccator before weighing them. The median grain size of the sediment was determined by laser diffraction (Mastersizer 2000, Malvern Instruments Ltd, UK). Freeze dried sediment was rehydrated in distilled water and introduced into the sample dispersion unit (Hydro 2000 G, Malvern Instruments Ltd, UK) adding hexametaphosphate and sonicating to avoid aggregates. Laser obscuration was between 10-20\% and the measuring range between 0.02 and $2000 \mu \mathrm{m}$. 


\subsection{Numerical methods}

Denitrification activity rates $\left(r_{d}\right)(N=107)$ were calculated by linear regression from the sequential readings of the $\mathrm{N}_{2} \mathrm{O}$ sensors $(\mathrm{r}=0.89 \pm 0.02$ (mean \pm standard error), with an average of 66 point measurements). Raw $\mathrm{r}_{\mathrm{d}}$ values in $\mu \mathrm{M} \mathrm{N} \mathrm{N}_{2} \mathrm{O}$ core $^{-1} \mathrm{~h}^{-1}$ were transformed to $\mu \mathrm{mol} \mathrm{N}_{2} \mathrm{O}$ $\mathrm{m}^{-2} \mathrm{~h}^{-1}$ using the inner core section area. The apparent activation energy $\left(\mathrm{E}_{\mathrm{a}} ; \mathrm{kJ} \mathrm{mol}^{-1}\right)$ of the denitrification process was estimated according to the Arrhenius equation: $\frac{r_{d j}}{r_{d i}}=\exp \left[\frac{E_{a}}{R}\left(\frac{1}{T_{i}}-\right.\right.$ $\left.\left.\frac{1}{T_{j}}\right)\right]$ where $R$ is the gas constant $\left(8.314 \mathrm{~J} \mathrm{~K}^{-1} \mathrm{~mol}^{-1}\right) ; T$, the absolute temperature $\left({ }^{\circ} \mathrm{K}\right)$; and $\mathrm{r}_{\mathrm{d}}$, the denitrification activity rate. The subscripts ( $\mathrm{i}, \mathrm{j}$ ) indicate two different thermal conditions. Statistics were conducted using $\mathrm{R}$ version 3.3.0 ( $\mathrm{R}$ Development Core Team 2016). Linear mixed-effects models were performed using the lme and lmer functions within the nlme and lme4 R packages, respectively [Pinheiro et al., 2007; Bates et al., 2015]. Functions ANOVA of the $\mathrm{R}$ core package stats (R Development Core Team 2016), AICc (Akaike Information Criterion for a small sample size) of the package AICcmodavg [Mazerolle, 2016] and fixed, global explained variance and r.squaredGLMM of MuMIn [Bartoń, 2016] were used to select the best fitting model.

\subsection{Compiled data of DEN $E_{a}$ in aquatic ecosystems}

For comparison, we compiled data about the denitrification temperature dependence in aquatic ecosystems across literature (Table S2). For each study, the apparent activation energy $\left(\mathrm{E}_{\mathrm{a}} ; \mathrm{kJ}\right.$ $\mathrm{mol}^{-1}$ ) of the denitrification process was estimated by the Arrhenius equation above or by the slope of an Arrhenius plot of $\ln \left(r_{d}\right)$ as a function of $\mathrm{T}^{-1}$ when more than two temperature data were available.

\section{Results}

3.1. Denitrification temperature dependence in mountain lakes sediments

The denitrification activity rates $\left(\mathrm{r}_{\mathrm{d}}\right)$ measured ranged from 0.5 to $60.5 \mu \mathrm{mol} \mathrm{N} \mathrm{O} \mathrm{m}^{-2} \mathrm{~h}^{-1}$ (Table $\mathrm{S} 1$ ). The rates increased with the experimental temperature, and nitrate addition levels (Fig. 3a). Rates (mean \pm standard error) for 7,14 and $28 \mu \mathrm{M}$ nitrate added were at $5^{\circ} \mathrm{C} 2.2 \pm 0.3,4.6 \pm 0.5$, $11.3 \pm 1.2 \mu \mathrm{mol} \mathrm{N} \mathrm{O} \mathrm{m}^{-2} \mathrm{~h}^{-1}$, respectively, and at $15^{\circ} \mathrm{C} 6.6 \pm 0.8,12.7 \pm 0.9,27.0 \pm 2.9 \mu \mathrm{mol} \mathrm{N}_{2} \mathrm{O} \mathrm{m}^{-2}$ $\mathrm{h}^{-1}$, respectively.

From the measured rates, the apparent activation energy was estimated for each nitrate level (Table S1, average $\mathrm{E}_{\mathrm{a}}=67 \pm 4 \mathrm{~kJ} \mathrm{~mol}^{-1}$ ). DEN $\mathrm{r}_{\mathrm{d}}$ at $5^{\circ} \mathrm{C}$ had a larger influence on the $\mathrm{E}_{\mathrm{a}}$ values than those at $15^{\circ} \mathrm{C}$ as shown by a significant negative correlation $(\mathrm{r}=-0.51, \mathrm{p}=0.0001)$ between $\mathrm{E}_{\mathrm{a}}$ and $\ln \left(\mathrm{r}_{\mathrm{d}}\right)$ at $5^{\circ} \mathrm{C}$ and not significant at $15^{\circ} \mathrm{C}$.

$\mathrm{E}_{\mathrm{a}}$ values and their variation declined when the nitrate added increased (Fig. $3 \mathrm{~b}$ ). $\mathrm{E}_{\mathrm{a}}$ negatively correlated $(\mathrm{r}=-0.33, \mathrm{p}=0.01)$ with the initial experimental nitrate (water phase plus added) concentrations. $E_{a}$ at nitrate saturation was estimated by fitting a linear relationship between the inverse of nitrate concentration and $\mathrm{E}_{\mathrm{a}}$ (model 0 in Table 2). In this model, the intercept indicates the value of $E_{a}$ when the influence of nitrate concentration tends to zero.

The variation of the rates measured under the same conditions of temperature and nitrate concentration was markedly high. Therefore, we investigated whether the estimation of the Ea dependency on nitrate concentration could be improved by taking into account other 
experimental issues and the lake idiosyncrasy (Table 2). We developed alternative mixed regression models including different factors in the random part and maintaining the inverse of nitrate concentration as the only factor in the fixed part (see supporting information for details). The alternative models took into account: the five sensor performance; the autocorrelation intrinsic to subsequent experimental additions; the nitrate addition level; the order of the addition level (not all the experiments followed the complete sequence from 7 to $28 \mu \mathrm{M} \mathrm{NO}_{3}{ }^{-}$) and the lake of the core. The only models that significantly improved the initial model 1 were those accounting for the sensor effects (model 3 and 4 in Table 2). They showed the lower AICc values and explained more variance (ANOVA p-values of 0.047 and 0.008 for model 3 and 4, respectively). When we considered core, lake, autocorrelation or nitrate addition features did not improve the Ea estimation. We eventually selected model 4 as the best estimation because it is simpler than model 3. Consequently, the denitrification $\mathrm{E}_{\mathrm{a}}$ at nitrate saturation is estimated to be $46 \pm 7 \mathrm{~kJ} \mathrm{~mol}^{-1}$ (i.e., $\mathrm{Q}_{10}=1.7 \pm 0.4$ ) and the apparent $\mathrm{E}_{\mathrm{a}}$ to vary according to nitrate concentration as:

$\mathrm{E}_{\mathrm{a}}=46+419\left[\mathrm{NO}_{3}\right]^{-1}$

3.2. Comparison with other aquatic ecosystems

We identified a total of 21 previous studies (Table S2) to compare our results with estimations from other sites and methods. They included lakes [Cavari and Phelps, 1977; Messer and Brezonik, 1984; Myrstener et al., 2016], ponds [Veraart et al., 2011], streams [Holmes et al., 1996; Boulêtreau et al., 2012], rivers [Pfenning and McMahon, 1997; Pattinson et al., 1998; Silvennoinen et al., 2008], denitrification beds (i.e., carbon supply to promote denitrification in eutrophic rivers, [Cameron and Schipper, 2010; Warneke et al., 2011]), hyporheic [Sheibley et al., 2003] and riparian [Ambus, 1993] zones, groundwaters [Jørgensen et al., 2009], swamps [Westermann and Ahring, 1987], wetlands [King and Nedwell, 1984], estuaries [Brin et al., 2017] and marine environments [Rysgaard et al., 2004; Canion et al., 2014b; Canion et al., 2014a; Kraft et al., 2014; Brin et al., 2017]. There is a large scattering in the $\mathrm{E}_{\mathrm{a}}$ values estimated. However, the most similar sites to those in our study [Rysgaard et al., 2004; Myrstener et al., 2016] were also from remote, cold and N-poor areas, and showed similar $E_{a}$ values plotted against the inverse of nitrate (Fig. 4).

\section{Discussion}

4.1. Denitrification rates, nitrate, and temperature

The denitrification rates $\left(\mathrm{r}_{\mathrm{d}}\right)$ obtained were similar to the few other measurements in mountain lake sediments [McCrackin and Elser, 2012; Vila-Costa et al., 2016]. The values are in the low range of freshwater sediments [Seitzinger, 1988; Piña-Ochoa and Alvarez-Cobelas, 2006] as expected from cold and oligotrophic environments. However, despite the apparent harsh conditions, the denitrification activity intensifies with increasing nitrate and temperature without becoming saturated (Fig. 3a) within the range of values currently found in the Pyrenees [Camarero and Catalan, 2012]. Therefore, the current denitrification potential of these systems

can respond to warming or increased $\mathrm{N}_{\mathrm{r}}$ deposition (or watershed loading) without any time lag. It could be argued that the experimental sequential procedure of $72 \mathrm{~h}$ incubations could facilitate an enrichment of denitrifiers in our experiment. We used the shortest time to obtain reliable measurements of the activity rate without disturbing the sediment interface. An alternative 
experimental design, based on pseudo-replicates of several cores from the same site incubated at the various levels of nitrate and temperature, would notably increase the sample-related heterogeneity due to the patchy nature of any sediment. We think that the cold and oligotrophic conditions of the studied system prevent any significant enrichment in denitrifiers during the experimental development.

In the compiled DEN $\mathrm{E}_{\mathrm{a}}$ studies, there are variable values for similar $\mathrm{NO}_{3}{ }^{-}$enrichments (Fig. 4), which may be attributed to changing assemblages of denitrifiers. A case of a latitudinal gradient in coastal marine sediments, with higher values for subtropical locations (121 and $\left.100 \mathrm{~kJ} \mathrm{~mol}^{-1}\right)$ [Canion et al., 2014b]. A case of cultures with a different nitrate reducing dominant species, Pseudomonas sp. or Vibrio sp., with 98 and $60 \mathrm{~kJ} \mathrm{~mol}^{-1} \mathrm{E}_{\mathrm{a}}$ values, respectively, isolated at 10 and $25^{\circ} \mathrm{C}$ from a salt-marsh sediment [King and Nedwell, 1984]. And cases of seasonal variability, with $E_{a}$ ranges of 70 to 76,36 to 53 and 38 to $60 \mathrm{~kJ} \mathrm{~mol}^{-1}$ in swamp, estuary and continental shelf sediments from temperate ecosystems, respectively [Westermann and Ahring, 1987; Brin et al., 2017]. Beyond the sequential experimental issue, different denitrifier assemblages between lakes could also be a source of variation in our data. However, models including the lake site as a source of random variation did not improve the fitting (Table 2). Only the use of molecular techniques to characterize the microbial assemblages (i.e., 16S rRNA) will settle discussions about this issue and clarify the relative influence of physicochemical and biological constraints.

To our knowledge, only another study measured DEN activities experimentally controlling both temperature and nitrate gradients close to the in situ conditions [Pattinson et al., 1998]. In this study, $\mathrm{E}_{\mathrm{a}}$ values also declined with increasing nitrate. Provided the difference of about three orders of magnitude in nitrate concentrations between the two studies, one has to conclude that DEN saturation by nitrate is achieved at different concentrations in eutrophic and oligotrophic ecosystems. Even so, the range of $\mathrm{E}_{\mathrm{a}}$ estimated in the eutrophic experiment fell within the $95 \%$ confidence limit of our model (Fig. 4).

The higher $\mathrm{E}_{\mathrm{a}}$ values (155-179 $\mathrm{kJ} \mathrm{mol}^{-1}$ ) have been found in eutrophic ponds [Veraart et al., 2011]. In this case, there was not an experimental forcing of the anoxia, so the authors attribute the high effect of warming on denitrification rates to a decline in the oxygen interference due to a synergic effect of lowering both the oxygen solubility and the production/respiration ratio when the temperature increases. Boulêtreau et al. 2012 also found a high $\mathrm{E}_{\mathrm{a}}\left(137 \mathrm{~kJ} \mathrm{~mol}^{-1}\right)$ : they were using a wide, and high experimental temperature range $\left(1-40^{\circ} \mathrm{C}\right)$ compared to the in situ temperature $\left(7.2 \pm 1.7^{\circ} \mathrm{C}\right)$ of their sites. The same experimental set, indicate a lower $\mathrm{E}_{\mathrm{a}}(43 \mathrm{~kJ}$ $\left.\mathrm{mol}^{-1}\right)$ when calculated only for a narrower temperature range $\left(1-12^{\circ} \mathrm{C}\right)$ closer to that in situ (Table S2). The lowest $\mathrm{E}_{\mathrm{a}}$ values $\left(<20 \mathrm{~kJ} \mathrm{~mol}^{-1}\right)$ were found by Cameron and Schipper [2010]. Coupled nitrification could also interfere the DEN experiments if ammonium levels are high. Sheibley et al. [2003] performed the only study of DEN $\mathrm{E}_{\mathrm{a}}$ at markedly low nitrate concentrations without any addition. Their $\mathrm{E}_{\mathrm{a}}$ estimates depart from our model (Fig. 4). In that case, there was an intense nitrification, also highly dependent on temperature and ammonium concentrations $(22 \mu \mathrm{M})$, and $\mathrm{DEN} \mathrm{E}_{\mathrm{a}}$ was estimated using activity rates at different seasons as a surrogate for temperature control.

In our compiled data, including our study, we did not find any significant correlation between DEN $E_{\mathrm{a}}$ values and any statistical temperature descriptor $(\mathrm{T} \max , \mathrm{T}$ min, $\mathrm{T}$ mean, $\mathrm{T}$ in situ or annual $\mathrm{T}$ mean, Table S2). Canion et al. [2014b] found a higher DEN $\mathrm{E}_{\mathrm{a}}$ value for warmer (subtropical) than colder (temperate or polar) environments. They suggested an adaptation of denitrifiers to in situ temperature, supported by a previous study in the polar region [Canion et 
al., 2013]. Although not universally, there are trade-offs between genetic adaptation to low and high temperature [Bennett and Lenski, 2007]. In a salt-march study, culture isolates at 10, and $25^{\circ} \mathrm{C}$ from the same sediment sample resulted in different nitrate-reducing dominant species, Pseudomonas sp. and Vibrio sp., and showed different $\mathrm{E}_{\mathrm{a}}$ (98 and $60 \mathrm{~kJ} \mathrm{~mol}^{-1}$, respectively). The highest $\mathrm{E}_{\mathrm{a}}$ was in the culture isolated at the closer temperature to in situ $\left(15^{\circ} \mathrm{C}\right)$ [King and Nedwell, 1984]. Recurrently, $\mathrm{DEN} \mathrm{E}_{\mathrm{a}}$ values are higher when obtained from temperatures around in situ. In the literature data, a mean increase of $42 \pm 11 \%( \pm \mathrm{se})$ is achieved when $\mathrm{E}_{\mathrm{a}}$ is calculated with a narrow temperature range close to the in situ one compared with the result using the complete temperature range of the experiment (Table S2). We found a similar increase (51\%) when the temperature range was reduced to values close to the in situ temperature in the samples of Lake Redon (Table S2). Consequently, we highlight the convenience of measuring DEN temperature dependence as close as possible to in situ conditions of temperature.

In the current context of results (Fig. 4), it seems necessary to recommend experiments following a common procedure including an experimental nitrate gradient and temperatures no more than $15{ }^{\circ} \mathrm{C}$ beyond the in situ values. The spatial or temporal distribution of the samples should not be a surrogate for these gradients.

\subsection{Carbon limitation, nitrate supply and competing process}

There were two aspects with potential influence on DEN temperature dependence (Fig. 1) that we did not explicitly consider, carbon limitation and competing processes. We did not expect a denitrification limitation by carbon in the Pyrenean mountain lakes. There is a higher ratio of primary production to respiration in both the water column and the surface sediments, resulting in an elevated fresh carbon stock for bacterial activity [Camarero et al., 1999]. All in all, our experimental measurements were made with the addition of glucose. In fact, one can expect a $\mathrm{C}$ availability influence on the denitrification-temperature dependence mostly in warm and eutrophic (nitrate-rich) aquatic ecosystems. The lowest DEN $E_{a}$ values $\left(<20 \mathrm{~kJ} \mathrm{~mol}^{-1}\right)$ in the compiled data were found by Cameron and Schipper [2010] in an extended 10-months incubation experiment. The low $\mathrm{E}_{\mathrm{a}}$ values could be due to a $\mathrm{C}$-limitation in the warmer treatments using labile $\mathrm{C}$ sources (green waste, maize cobs, and wheat straw). $\mathrm{C}$ deficiency could also cause the low $\mathrm{E}_{\mathrm{a}}\left(26 \mathrm{~kJ} \mathrm{~mol}^{-1}\right)$ assessed in a Pseudomonas aeruginosa culture isolated from Lake Kinneret as there was no addition of any C source [Cavari and Phelps, 1977; Gal et al., 2003].

In the method that we applied, the experimental assumption is that nitrification is not acting because of the induced anoxic conditions and the inhibition of the ammonium monooxygenase by acetylene [Hynes and Knowles, 1978]. Consequently, sources of $\mathrm{NO}_{3}{ }^{-}$supply variation restrict to diffusive transport and uptake by alternative biogeochemical pathways. Nitrate diffusion aspects appear to have had no significant influence in our experiment as core and lake factors, which implicitly account for differences in sediment particle size, did not improve the models (Table 2).

Nitrate uptake, anammox and dissimilatory nitrate reduction to ammonium (DNRA) are the biogeochemical processes that can compete with DEN for nitrate. We may assume that nitrate assimilation should not be relevant because of the high abundance of ammonium - the preferred $\mathrm{N}$ source [Luque-Almagro et al., 2011] - and the common low rates of nitrogen uptake in dark conditions [Lorenzen et al., 1998].

Anammox competes with DEN for nitrite. To our knowledge, there is no evidence of the dominance of anammox or DEN depending on the nitrate concentration. Anammox seems more 
sensitive to nitrate fluctuations than DEN [Rysgaard et al., 2004]. The highest anammox activity respect to DEN has been found at $5^{\circ} \mathrm{C}$ in Arctic marine sediments [Rysgaard et al., 2004]. Canion et al. [2014a] found similar results in Arctic fjord sediments with anammox bacteria being more specialized for psychrophilic activity than denitrification. Recently, Brin et al. [2017] in a warmer habitat, temperate marine sediments, did not find differences in temperature responses for the two processes.

The ratio of electron acceptor (i.e., $\mathrm{NO}_{3}{ }^{-}$) to electron donor (i.e., organic $\mathrm{C}$ ) is the most frequently mentioned partitioning factor between DEN and DNRA [Tiedje et al., 1982]. DNRA is the dominant pathway under nitrate-limited conditions, while DEN is the favored pathway under nitrate-replete conditions [Smith et al., 1982; King and Nedwell, 1985; 1987; Herbert and Nedwell, 1990; Laverman et al., 2006; Dong et al., 2009; Mania et al., 2014; Nogaro and Burgin, 2014]. Slightly more energy is obtained per mol of $\mathrm{NO}_{3}{ }^{-}$by DNRA than by DEN [Strohm et al., 2007] and, additionally, DNRA consumes more electrons (8 vs. 5) during the reduction of $\mathrm{NO}_{3}{ }^{-}$to $\mathrm{NH}_{4}^{+}$[Burgin and Hamilton, 2007]. Low $\mathrm{NO}_{3}{ }^{-}$and high organic $\mathrm{C}$ availability can thus create more favorable conditions for DNRA than DEN [MacFarlane and Herbert, 1982; Tiedje et al., 1982]. The in situ $\mathrm{C} / \mathrm{N}$ ratios of the sediment (Table 1) were always higher than 10 in our samples, in the range of values more favorable to DNRA. A C/N ratio for an equal contribution of the two processes of nitrate reduction is c. 7.5 [Yoon et al., 2015]). In all our experimental treatments, the DOC/nitrate ratio was above 100 (a/a), thus with similar conditions favoring DNRA as in field conditions.

Some studies have also shown a dominance of DNRA over DEN at higher temperatures [Ogilvie et al., 1997; Yoon et al., 2015]. This dominance could be temporal during summer periods [King and Nedwell, 1984; Jørgensen, 1989] or spatial as occurs in some warm tropical ecosystems [Dong et al., 2011]. Nonetheless, this apparent temperature effect may mask the true influence of the co-occurring higher reducing conditions and lower nitrate concentrations at higher temperatures that eventually determine a low ratio of electron acceptor to electron donor [Jørgensen, 1989; Gardner et al., 2006; Gardner and McCarthy, 2009; Gross-Wittke et al., 2010; Nizzoli et al., 2010; Zhu-Barker et al., 2015]. The only two studies with data of temperature dependence for the two nitrate reduction processes are at a high nitrate concentration (1 $\mathrm{mM})$. Kraft et al. [2014] shows $\mathrm{E}_{\mathrm{a}}$ values of 22 and $40 \mathrm{~kJ} \mathrm{~mol}^{-1}$, for DEN and DNRA respectively, in the complete experimental range of temperatures $\left(10\right.$ to $\left.30^{\circ} \mathrm{C}\right)$, and 26 and $79 \mathrm{~kJ}$ $\mathrm{mol}^{-1}$, respectively, in a narrow segment of temperature $\left(10\right.$ to $\left.15^{\circ} \mathrm{C}\right)-$ based on $\mathrm{E}_{\mathrm{a}}$ values calculated from Fig. S8A. Yoon et al. [2015] investigated the switch between the two processes in a single microbial model, Shewanella loihica, a species capable of performing the two pathways. They found a dominance of DNRA at warmer temperatures, with DEN showing a decline from 21 to $30^{\circ} \mathrm{C}$ and a null activity at $37^{\circ} \mathrm{C}$. Temperature does not appear to be an issue in our experiment concerning DNRA and DEN partition. Using slurry incubations overestimate DNRA by enhancing nitrate availability to deeper layers of the sediments, where ammonifiers dominate over denitrifiers [Behrendt et al., 2013]. This procedure could have affected other DEN estimates in mountain lakes [Vila-Costa et al., 2016] but their results do not differ markedly from our ones.

The generation of $\mathrm{N}_{2} \mathrm{O}$ due to abiotic processes could let to an overestimation of the denitrification activity. At the current stage of knowledge, it is hard to infer any contribution of chemical processes to the overall $\mathrm{NO}$ and $\mathrm{N}_{2} \mathrm{O}$ production [Schreiber et al., 2012]. There are two major abiotic $\mathrm{N}_{2} \mathrm{O}$ production pathways. The $\mathrm{NH}_{2} \mathrm{OH}$ decomposition to $\mathrm{N}_{2} \mathrm{O}$ at circumneutral $\mathrm{pH}$ is favored by high $\mathrm{Mn}$ (IV), temperature and salinity, and low organic carbon. The 
chemodenitrification of $\mathrm{NO}$ and $\mathrm{NO}_{2}{ }^{-}$to $\mathrm{N}_{2} \mathrm{O}$ is favored by high $\mathrm{pH}$, low $\mathrm{O}_{2}$ and solid Fe (III) or $\mathrm{Cu}$ (II) catalysts [Zhu-Barker et al., 2015]. Few of these favorable conditions are present in the studied lakes (e.g., the granitic nature of the bedrock in the studied lakes confers low levels of iron to the sediments [Catalan et al., 2014]). However, these processes may be relevant in watersheds of metamorphic rocks rich in metals, which are common in some parts of the Pyrenees and other mountain ranges [Catalan et al., 1993].

We can conclude that DNRA, at nitrate limiting conditions and high temperature, and anammox, at low temperature and $\mathrm{C} / \mathrm{N}$, are the most like processes influencing DEN yield in mountain lakes. Future experiments on the temperature dependence of DEN, Anammox, and DNRA across gradients of nitrate, $\mathrm{C} / \mathrm{N}$ and temperature are necessary to clarify these interactions.

\section{Conclusions}

There is still a limited knowledge about denitrification rates and their temperature dependence in general and, particularly, for cold and N-poor systems, despite that the latter cover a high percentage of the continental aquatic ecosystems. Our study shows that the low rates of denitrification observed are not nitrate saturated and the system can respond to warming and increased $\mathrm{N}_{\mathrm{r}}$ loadings, either from deposition or the watershed. The case-by-case estimation of DEN $E_{a}$ present much variability, but there is a robust statistical behavior that can be applied to modeling, upscaling and as a benchmark for actual measurements. Three main conclusions derive from our results:

1. Under nitrate saturation conditions (e.g., $>100 \mu \mathrm{M})$ a $D E N E_{a}$ significantly different from $46 \mathrm{~kJ} \mathrm{~mol}^{-1}$ (e.g., $>67$ or $<31$ ) would suggest that there is another factor interfering (e.g., $\mathrm{C}$ quality or quantity limitation; or very distinct microbial assemblage related to other features of the system).

2. Below saturation and not at extremely low nitrate levels $(>3 \mu \mathrm{M})$, equation (1) can be applied for modeling the temperature influence on DEN rates, accounting for nitrate levels.

3. In the natural environments of remote areas, in situ nitrate values are still far from DEN saturation. Currently, this feature leads to very high apparent DEN Ea values but this does not mean that with warming higher DEN rates could be sustained. In case of temperature increase, a short transitory period of high DEN would lead to a rapid depletion of nitrate unless nitrate supply rates would proportionally increase. Therefore, in a warmer scenario, variation in denitrification rates will continue mostly depending on nitrate supply processes that include proximal (e. g., sediment-related nitrification), local (e. g., $\mathrm{Nr}$ leaching from soils) and regional (e. g., atmospheric $\mathrm{Nr}$ deposition) components [Wallenstein et al., 2006].

\section{Acknowledgments}

Thanks to Berta Fueyo, Marc Sala-Faig, Rober Sánchez and Pau Giménez-Grau for help in the laboratory and field sampling. The Spanish Government provided funds through the research grants of the Ministerio de Economia y Competitividad: NitroPir (CGL2010-19737), Lacus (CGL2013-45348-P) and Transfer (CGL2016-80124-C2-1-P) and a predoctoral fellowship to CPL (FPU12-00644). All the experimental and compiled data is available in the supporting info. 


\section{References}

Ambus, P. (1993), Control of denitrification enzyme-activity in a streamside soil, FEMS Microbiol. Ecol., 102(3-4), 225-234.

Andersen, K., T. Kjaer, and N. P. Revsbech (2001), An oxygen insensitive microsensor for nitrous oxide, Sensors and Actuators B-Chemical, 81(1), 42-48.

Arrhenius, S. (1915), The influence of temperature on the velocity of reactions - Reactions of cells., in Quantitative Laws in Biological Chemistry, edited by G. B. a. Sons, pp. 1-164, Ltd., London.

Bachand, P. A. M., and A. J. Horne (2000), Denitrification in constructed free-water surface wetlands: II. Effects of yegetation and temperature, Ecol. Eng., 14(1-2), 17-32.

Balderston, W. L., B. Sherr, and W. Payne (1976), Blockage by acetylene of nitrous oxide reduction in Pseudomonas perfectomarinus, Appl. Environ. Microbiol., 31(4), 504-508.

Baron, J. S., E. K. Hall, B. T. Nolan, J. C. Finlay, E. S. Bernhardt, J. A. Harrison, F. Chan, and E. W. Boyer (2013), The interactive effects of excess reactive nitrogen and climate change on aquatic ecosystems and water resources of the United States, Biogeochemistry, 114(1), 71-92.

Bartoń, K. (2016), MuMIn: multi-model inference. $\mathrm{R}$ package version1.15.6. https://CRAN.Rproject.org/package $=$ MuMIn, edited.

Bates, D., M. Mächler, B. Bolker, and S. Walker (2015), Fitting linear mixed-effects models using lme4, J. Stat. Softw., 67(1), 1-48.

Behrendt, A., D. de Beer, and P. Stief (2013), Vertical activity distribution of dissimilatory nitrate reduction in coastal marine sediments, Biogeosciences, 10(11), 7509-7523.

Bennett, A. F., and R. E. Lenski (2007), An experimental test of evolutionary trade-offs during temperature adaptation, Proceedings of the National Academy of Sciences, 104(suppl 1), 8649-8654.

Boulêtreau, S., E. Salvo, E. Lyautey, S. Mastrorillo, and F. Garabetian (2012), Temperature dependence of denitrification in phototrophic river biofilms, Sci. Total Environ., 416, 323-328.

Brezonik, P. L. (1994), Chemical kinetics and process dynamics in aquatic systems, 754 pp., Lewis Publishers, Boca Raton.

Brin, L. D., A. E. Giblin, and J. J. Rich (2014), Environmental controls of anammox and denitrification in southern New England estuarine and shelf sediments, Limnol. Oceanogr., 59(3), 851-860.

Brin, L. D., A. E. Giblin, and J. J. Rich (2017), Similar temperature responses suggest future climate warming will not alter partitioning between denitrification and anammox in temperate marine sediments, Glob. Chang. Biol., 23, 331-340.

Burgin, A. J., and S. K. Hamilton (2007), Have we overemphasized the role of denitrification in aquatic ecosystems? A review of nitrate removal pathways., Front. Ecol. Environ., 5(2 ), 89-96.

Camarero, L., and J. Catalan (2012), Atmospheric phosphorus deposition may cause lakes to revert from phosphorus limitation back to nitrogen limitation, Nat. Commun., 3 .

Camarero, L., M. Felip, M. Ventura, F. Bartumeus, and J. Catalan (1999), The relative importance of the planktonic food web in the carbon cycle of an oligotrophic mountain lake in a poorly vegetated catchment (Redó, Pyrenees), $J$. Limnol., 58(2), 203-212.

Cameron, S. G., and L. A. Schipper (2010), Nitrate removal and hydraulic performance of organic carbon for use in denitrification beds, Ecol. Eng., 36(11), 1588-1595.

Canion, A., O. Prakash, S. J. Green, L. Jahnke, M. M. M. Kuypers, and J. E. Kostka (2013), Isolation and physiological characterization of psychrophilic denitrifying bacteria from permanently cold Arctic fjord sediments (Svalbard, Norway), Environ. Microbiol., 15(5), 1606-1618.

Canion, A., W. A. Overholt, J. E. Kostka, M. Huettel, G. Lavik, and M. M. M. Kuypers (2014a), Temperature response of denitrification and anaerobic ammonium oxidation rates and microbial community structure in Arctic fjord sediments, Environ. Microbiol., 16(10), 3331-3344.

Canion, A., J. Kostka, T. Gihring, M. Huettel, J. Van Beusekom, H. Gao, G. Lavik, and M. Kuypers (2014b), Temperature response of denitrification and anammox reveals the adaptation of microbial communities to in situ temperatures in permeable marine sediments that span $50^{\circ}$ in latitude, Biogeosciences, 11(2), 309-320.

Castellano-Hinojosa, A., D. Correa-Galeote, P. Carrillo, E. J. Bedmar, and J. M. Medina-Sánchez (2017), Denitrification and Biodiversity of Denitrifiers in a High-Mountain Mediterranean Lake, Front. Microbiol., 8(1911). Catalan, J., S. Pla-Rabés, J. García, and L. Camarero (2014), Air temperature-driven CO2 consumption by rock weathering at short timescales: Evidence from a Holocene lake sediment record, Geochimica et Cosmochimica Acta, $136,67-79$. 
Catalan, J., E. Ballesteros, E. Gacia, A. Palau, and L. Camarero (1993), Chemical composition of disturbed and undisturbed high-mountain lakes in the Pyrenees: A reference for acidified sites, Water Res, 27(1), $133-141$.

Catalan, J., S. Pla-Rabes, A. P. Wolfe, J. P. Smol, K. M. Ruhland, N. J. Anderson, J. Kopacek, E. Stuchlik, R. Schmidt, K. A. Koinig, L. Camarero, R. J. Flower, O. Heiri, C. Kamenik, A. Korhola, P. R. Leavitt, R. Psenner, and I. Renberg (2013), Global change revealed by palaeolimnological records from remote lakes: a review, J. Paleolimnol., 49(3), 513-535.

Catalan, J., M. Ventura, A. Brancelj, I. Granados, H. Thies, U. Nickus, A. Korhola, A. F. Lotter, A. Barbieri, E. Stuchlík, L. Lien, P. Bitušík, T. Buchaca, L. Camarero, G. H. Goudsmit, J. Kopáćek, G. Lemcke, D. M. Livingstone, B. Müller, M. Rautio, M. Šiško, S. Sorvari, F. Šporka, O. Strunecký, and M. Toro (2002), Seasonal ecosystem variability in remote mountain lakes: implications for detecting climatic signals in sediment records, J. Paleolimnol., 28(1), 25-46.

Cavari, B. Z., and G. Phelps (1977), Denitrification in lake Kinneret in presence of oxygen, Freshwater Biol., 7(4), 385-391.

Chambers, J. M. (1992), Linear models, Wadsworth \& Brooks/Cole, Pacific Grove, California.

Crowther, T. W., and M. A. Bradford (2013), Thermal acclimation in widespread heterotrophic soil microbes, Ecol Lett, 16(4), 469-477.

Dong, L. F., C. J. Smith, S. Papaspyrou, A. Stott, A. M. Osborn, and D. B. Nedwell (2009), Changes in benthic denitrification, nitrate ammonification, and anammox process rates and nitrate and nitrite reductase gene abundances along an estuarine nutrient gradient (the Colne estuary, United Kingdom), Appl. Environ. Microbiol., 75(10), 31713179 .

Dong, L. F., M. N. Sobey, C. J. Smith, I. Rusmana, W. Phillips, A. Stott, A. M. Osborn, and D. B. Nedwell (2011), Dissimilatory reduction of nitrate to ammonium, not denitrification or anammox, dominates benthic nitrate reduction in tropical estuaries, Limnol. Oceanogr., 56(1), 279-291.

Erisman, J. W., J. Galloway, S. Seitzinger, A. Bleeker, and K. Butterbach-Bahl (2011), Reactive nitrogen in the environment and its effect on climate change, Curr. Opin. Environ. Sustainability., 3(5), 281-290.

Foley, J., D. de Haas, Z. Yuan, and P. Lant (2010), Nitrous oxide generation in full-scale biological nutrient removal wastewater treatment plants, Water Res, 44(3), 831-844.

Gal, G., J. Imberger, T. Zohary, J. Antenucci, A. Anis, and T. Rosenberg (2003), Simulating the thermal dynamics of Lake Kinneret, Ecol. Model., 162(1), 69-86.

Galloway, J. N. (2004), Nitrogen cycles: past, present, and future, Biogeochemistry, 70, 153-226.

Gardner, W. S., and M. J. McCarthy (2009), Nitrogen dynamics at the sediment-water interface in shallow, subtropical Florida Bay: why denitrification efficiency may decrease with increased eutrophication, Biogeochemistry, 95(2-3), 185-198.

Gardner, W. S., M. J. McCarthy, S. An, D. Sobolev, K. S. Sell, and D. Brock (2006), Nitrogen fixation and dissimilatory nitrate reduction to ammonium (DNRA) support nitrogen dynamics in Texas estuaries, Limnol. Oceanogr., 51(1), 558-568.

Glew, J. (1991), Miniature gravity corer for recovering short sediment cores, J. Paleolimnol., 5(3), $285-287$.

Greaver, T., C. Clark, J. Compton, D. Vallano, A. Talhelm, C. Weaver, L. Band, J. Baron, E. Davidson, and C. Tague (2016), Key ecological responses to nitrogen are altered by climate change, Nature Clim. Change, 6(9), 836843 .

Groffman, P. M., K. Butterbach-Bahl, R. W. Fulweiler, A. J. Gold, J. L. Morse, E. K. Stander, C. Tague, C. Tonitto, and P. Vidon (2009), Challenges to incorporating spatially and temporally explicit phenomena (hotspots and hot moments) in denitrification models, Biogeochemistry, 93(1-2), 49-77.

Groffman, P. M., M. A. Altabet, J. K. Bohlke, K. Butterbach-Bahl, M. B. David, M. K. Firestone, A. E. Giblin, T. M. Kana, L. P. Nielsen, and M. A. Voytek (2006), Methods for measuring denitrification: Diverse approaches to a difficult problem, Ecol. Appl., 16(6), 2091-2122.

Gross-Wittke, A., G. Gunkel, and A. Hoffmann (2010), Temperature effects on bank filtration: redox conditions and physical-chemical parameters of pore water at Lake Tegel, Berlin, Germany, J. Water Clim. Change, 1(1), 55-66.

Gruber, N., and J. N. Galloway (2008), An Earth-system perspective of the global nitrogen cycle, Nature, 451(7176), 293-296.

Hall, E. K., C. Neuhauser, and J. B. Cotner (2008), Toward a mechanistic understanding of how natural bacterial communities respond to changes in temperature in aquatic ecosystems, ISME J., 2(5), 471-481.

Hall, E. K., G. A. Singer, M. J. Kainz, and J. T. Lennon (2010), Evidence for a temperature acclimation mechanism in bacteria: an empirical test of a membrane-mediated trade-off, Funct. Ecol., 24(4), 898-908.

Heiri, O., A. F. Lotter, and G. Lemcke (2001), Loss on ignition as a method for estimating organic and carbonate content in sediments: reproducibility and comparability of results, J. Paleolimnol., 25(1), 101-110. 
Herbert, R. A., and D. B. Nedwell (1990), Role of environmental factors in regulating nitrate respiration in intertidal sediments, in Denitrification in soil and sediment, edited by N. P. Revsbech and J. Sørensen, pp. 77-90, Springer US, New York.

Holmes, R. M., J. B. Jones, S. G. Fisher, and N. B. Grimm (1996), Denitrification in a nitrogen-limited stream ecosystem, Biogeochemistry, 33(2), 125-146.

Holtgrieve, G. W., D. E. Schindler, W. O. Hobbs, P. R. Leavitt, E. J. Ward, L. Bunting, G. Chen, B. P. Finney, I. Gregory-Eaves, S. Holmgren, M. J. Lisac, P. J. Lisi, K. Nydick, L. A. Rogers, J. E. Saros, D. T. Selbie, M. D. Shapley, P. B. Walsh, and A. P. Wolfe (2011), A Coherent Signature of Anthropogenic Nitrogen Deposition to Remote Watersheds of the Northern Hemisphere, Science, 334(6062), 1545-1548.

Hynes, R. K., and R. Knowles (1978), Inhibition by acetylene of ammonia oxidation in Nitrosomonas europaea, FEMS Microbiol. Lett., 4(6), 319-321.

Jørgensen, C. J., O. S. Jacobsen, B. Elberling, and J. Aamand (2009), Microbial Oxidation of Pyrite Coupled to Nitrate Reduction in Anoxic Groundwater Sediment, Environ. Sci. Technol., 43(13), 4851-4857.

Jørgensen, K. S. (1989), Annual pattern of denitrification and nitrate ammonification in estuarine sediment, Appl. Environ. Microbiol., 55(7), 1841-1847.

King, D., and D. B. Nedwell (1984), Changes in the nitrate-reducing community of an anaerobic saltmarsh sediment in response to seasonal selection by temperature, Microbiology, 130(11), 2935-2941.

King, D., and D. B. Nedwell (1985), The influence of nitrate concentration upon the end-products of nitrate dissimilation by bacteria in anaerobic salt marsh sediment, FEMS Microbiol. Lett., 31(1), 23-28.

King, D., and D. B. Nedwell (1987), The adaptation of nitrate-reducing bacterial communities in estuarine sediments in response to overlying nitrate load, FEMS Microbiol. Ecol., 3(1), 15-20.

Kraft, B., H. E. Tegetmeyer, R. Sharma, M. G. Klotz, T. G. Ferdelman, R. L. Hettich, J. S. Geelhoed, and M. Strous (2014), The environmental controls that govern the end product of bacterial nitrate respiration, Science, 345(6197), 676-679.

Laverman, A. M., P. Van Cappellen, D. van Rotterdam-Los, C. Pallud, and J. Abell (2006), Potential rates and pathways of microbial nitrate reduction in coastal sediments, FEMS Microbiol. Ecol., 58(2), 179-192.

Lorenzen, J., L. H. Larsen, T. Kjaer, and N. P. Revsbech (1998), Biosensor determination of the microscale distribution of nitrate, nitrate assimilation, nitrification, and denitrification in a diatom-inhabited freshwater sediment, Appl. Environ. Microbiol., 64(9), 3264-3269.

Luque-Almagro, V. M., A. J. Gates, C. Moreno-Vivian, S. J. Ferguson, D. J. Richardson, and M. Dolores Roldan (2011), Bacterial nitrate assimilation: gene distribution and regulation, Biochem. Soc. Trans., 39, $1838-1843$.

MacFarlane, G., and R. Herbert (1982), Nitrate dissimilation by Vibrio spp. isolated from estuarine sediments, Microbiology, 128(10), 2463-2468.

Mania, D., K. Heylen, R. J. M. van Spanning, and A. Frostegard (2014), The nitrate-ammonifying and nosZcarrying bacterium Bacillus vireti is a potent source and sink for nitric and nitrous oxide under high nitrate conditions, Environ. Microbiol., 16(10), 3196-3210.

Mazerolle, M. J. (2016), AICcmodavg: model selection and multimodel inference based on (Q) AIC (c). R package version 2.0-4 http://CRAN.R-project.org/package=AICcmodavg, edited.

McClain, M. E., E. W. Boyer, C. L. Dent, S. E. Gergel, N. B. Grimm, P. M. Groffman, S. C. Hart, J. W. Harvey, C. A. Johnston, and E. Mayorga (2003), Biogeochemical hot spots and hot moments at the interface of terrestrial and aquatic ecosystems, Ecosystems, 6(4), 301-312.

McCrackin, M. L., and J. J. Elser (2010), Atmospheric nitrogen deposition influences denitrification and nitrous oxide production in lakes, Ecology, 91(2), 528-539.

McCrackin, M. L., and J. J. Elser (2012), Denitrification kinetics and denitrifier abundances in sediments of lakes receiving atmospheric nitrogen deposition (Colorado, USA), Biogeochemistry, 108(1), 39-54.

Messer, J. J., and P. L. Brezonik (1984), Laboratory evaluation of kinetic-parameters for lake sediment denitrification models, Ecol. Model., 21(4), 277-286.

Myrstener, M., A. Jonsson, and A. K. Bergstrom (2016), The effects of temperature and resource availability on denitrification and relative N2O production in boreal lake sediments, J. Environ. Sci., 47, 82-90.

Nizzoli, D., E. Carraro, V. Nigro, and P. Viaroli (2010), Effect of organic enrichment and thermal regime on denitrification and dissimilatory nitrate reduction to ammonium (DNRA) in hypolimnetic sediments of two lowland lakes, Water Res., 44(9), 2715-2724.

Nogaro, G., and A. J. Burgin (2014), Influence of bioturbation on denitrification and dissimilatory nitrate reduction to ammonium (DNRA) in freshwater sediments, Biogeochemistry, 120(1-3), 279-294.

Ogilvie, B., M. Rutter, and D. Nedwell (1997), Selection by temperature of nitrate-reducing bacteria from estuarine sediments: species composition and competition for nitrate, FEMS Microbiol. Ecol., 23(1), 11-22. 
Parkin, T. B. (1987), Soil microsites as a source of denitrification variability, Soil Sci. Soc. Am. J., 51(5), 1194-1199. Pattinson, S. N., R. Garcia-Ruiz, and B. A. Whitton (1998), Spatial and seasonal variation in denitrification in the Swale-Ouse system, a river continuum, Sci. Total Environ., 210(1-6), 289-305.

Pfenning, K., and P. McMahon (1997), Effect of nitrate, organic carbon, and temperature on potential denitrification rates in nitrate-rich riverbed sediments, J. Hydrol., 187(3), 283-295.

Piña-Ochoa, E., and M. Alvarez-Cobelas (2006), Denitrification in aquatic environments: A cross-system analysis, Biogeochemistry, 81(1), 111-130.

Pinheiro, J., D. Bates, S. DebRoy, and D. Sarkar (2007), Linear and nonlinear mixed effects models, in $R$ package version, edited, p. 57.

Pinheiro, J. C., and D. M. Bates (1978), Mixed-Effects Models in S and S-plus, 528 pp., Springer, New York, NY.

R Development Core Team (2016), R: A Language and Environment for Statistical Computing. Available at: http://www.r-project.org., edited.

Rockstrom, J., W. Steffen, K. Noone, A. Persson, F. S. Chapin, 3rd, E. F. Lambin, T. M. Lenton, M. Scheffer, C. Folke, H. J. Schellnhuber, B. Nykvist, C. A. de Wit, T. Hughes, S. van der Leeuw, H. Rodhe, S. Sorlin, P. K. Snyder, R. Costanza, U. Svedin, M. Falkenmark, L. Karlberg, R. W. Corell, V. J. Fabry, J. Hansen, B. Walker, D. Liverman, K. Richardson, P. Crutzen, and J. A. Foley (2009), A safe operating space for humanity, Nature, 461(7263), 472-475.

Rysgaard, S., R. N. Glud, N. Risgaard-Petersen, and T. Dalsgaard (2004), Denitrification and anammox activity in Arctic marine sediments, Limnol. Oceanogr., 49(5), 1493-1502.

Schreiber, F., P. Wunderlin, K. M. Udert, and G. F. Wells (2012), Nitric oxide and nitrous oxide turnover in natural and engineered microbial communities: biological pathways, chemical reactions, and novel technologies, Front. Microbiol., 3 .

Seitzinger, S., J. A. Harrison, J. K. Bohlke, A. F. Bouwman, R. Lowrance, B. Peterson, C. Tobias, and G. Van Drecht (2006), Denitrification across landscapes and waterscapes: A synthesis, Ecol. Appl., 16(6), 2064-2090.

Seitzinger, S. P. (1988), Denitrification in fresh-water and coastal marine ecosystems- ecological and geochemical significance, Limnol. Oceanogr., 33(4), 702-724.

Sheibley, R. W., A. P. Jackman, J. H. Duff, and F. J. Triska (2003), Numerical modeling of coupled nitrificationdenitrification in sediment perfusion cores from the hyporheic zone of the Shingobee River USA, Adv. Water. Resour., 26(9), 977-987.

Silvennoinen, H., A. Liikanen, J. Torssonen, C. F. Stange, and P. J. Martikainen (2008), Denitrification and N(2)O effluxes in the Bothnian Bay (northern Baltic Sea) river sediments as affected by temperature under different oxygen concentrations, Biogeochemistry, 88(1), 63-72.

Smith, C., R. DeLaune, and W. Patrick (1982), Nitrate reduction in Spartina alterniflora marsh soil, Soil Sci. Soc. Am. J., 46(4), 748-750.

Smol, J. P. (2012), A planet in flux: How is life on Earth reacting to climate change?, Nature, 483, S12-S15.

Stoddard, J. L. (1994), Long-term changes in watershed retention of nitrogen. Its causes and aquatic consequences, in Environmental Chemistry of Lakes and Reservoirs, edited by L. A. Baker, pp. 223-284, Am. Chem. Soc., Washington, DC.

Strohm, T. O., B. Griffin, W. G. Zumft, and B. Schink (2007), Growth yields in bacterial denitrification and nitrate ammonification, Appl. Environ. Microbiol., 73(5), 1420-1424.

Tiedje, J. M. (1988), Ecology of denitrification and dissimilatory nitrate reduction to ammonium, in Biology of anaerobic microorganisms, edited by A. J. B. Zehnder, pp. 179-244, John Wiley \& Sons, New York.

Tiedje, J. M., A. J. Sexstone, D. D. Myrold, and J. A. Robinson (1982), Denitrification: ecological niches, competition and survival, Antonie van Leeuwenhoek, 48(6), 569-583.

Veraart, A. J., J. J. M. de Klein, and M. Scheffer (2011), Warming Can Boost Denitrification Disproportionately Due to Altered Oxygen Dynamics, Plos One, 6(3).

Vila-Costa, M., M. Bartrons, J. Catalan, and E. O. Casamayor (2014), Nitrogen-Cycling Genes in Epilithic biofilms of oligotrophic high-altitude lakes (Central Pyrenees, Spain), Microb. Ecol., 68(1), 60-69.

Vila-Costa, M., C. Pulido, E. Chappuis, A. Calviño, E. O. Casamayor, and E. Gacia (2016), Macrophyte landscape modulates lake ecosystem-level nitrogen losses through tightly coupled plant-microbe interactions, Limnol. Oceanogr., 61, 78-88.

Wallenstein, M. D., D. D. Myrold, M. Firestone, and M. Voytek (2006), Environmental controls on denitrifying communities and denitrification rates: Insights from molecular methods, Ecol. Appl., 16(6), 2143-2152.

Warneke, S., L. A. Schipper, D. A. Bruesewitz, I. McDonald, and S. Cameron (2011), Rates, controls and potential adverse effects of nitrate removal in a denitrification bed, Ecol. Eng., 37(3), 511-522.

Weiss, R. F., and B. A. Price (1980), Nitrous oxide solubility in water and seawater, Mar. Chem., 8(4), 347-359. 


\section{Water Resources Research}

Westermann, P., and B. K. Ahring (1987), Dynamics of methane production, sulfate reduction, and denitrification in a permanently waterlogged alder swamp, Appl. Environ. Microbiol., 53(10), 2554-2559.

Yoon, S., C. Cruz-Garcia, R. Sanford, K. M. Ritalahti, and F. E. Loffler (2015), Denitrification versus respiratory ammonification: environmental controls of two competing dissimilatory NO3-/NO2- reduction pathways in Shewanella loihica strain PV-4, ISME J, 9(5), 1093-1104.

Yoshinari, T., and R. Knowles (1976), Acetylene inhibition of nitrous-oxide reduction by denitrifying bacteria, Biochem. Bioph. Res. Co., 69(3), 705-710.

Zhu-Barker, X., A. Cavazos, N. Ostrom, W. Horwath, and J. Glass (2015), The importance of abiotic reactions for nitrous oxide production, Biogeochemistry, 126(3), 251-267.

Zuur, A., E. Ieno, N. Walker, A. Saveliev, and G. Smith (2009), Mixed effects models and extensions in ecology with $R ., 574$ pp., Springer-Verlag New York, New York, NY.

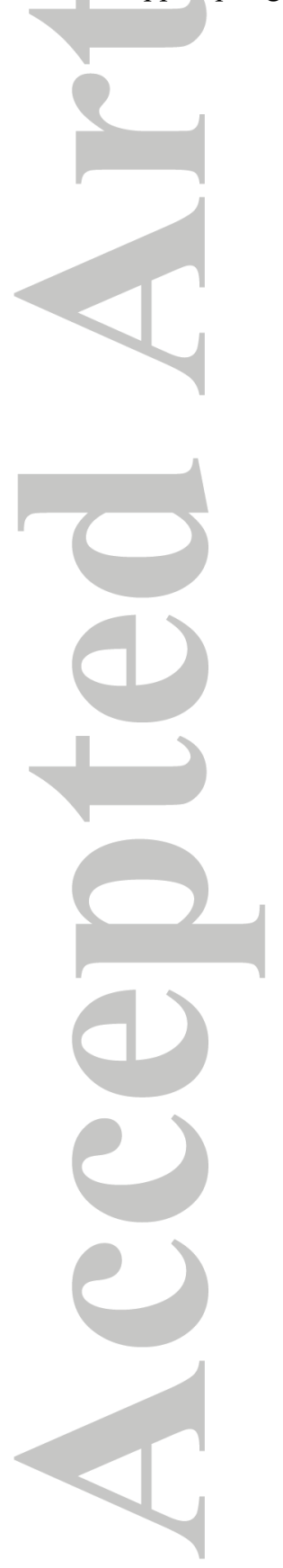


Water Resources Research

Table 1. Study sites location and characteristics.

\begin{tabular}{|c|c|c|c|}
\hline Lake & Redon & Plan & Llong \\
\hline Latitude (N) & 42.64208 & 42.62248 & 42.57431 \\
\hline Longitude (E) & 0.77951 & 0.9307 & 0.95063 \\
\hline Altitude (m a.s.l.) & 2235 & 2188 & 2000 \\
\hline Area (ha) & 24 & 5 & 7 \\
\hline $\begin{array}{l}\text { Maximum depth, } \\
\text { (m) }\end{array}$ & 73 & 9 & 12 \\
\hline Temperature ${ }^{\mathrm{a}}\left({ }^{\circ} \mathrm{C}\right)$ & 4 & 5 & 3 \\
\hline $\mathrm{NO}_{3}^{-\mathrm{a}}(\mu \mathrm{M})$ & $5(4-6)$ & $1(1-2)$ & $8(7-9)$ \\
\hline $\mathrm{NO}_{2}^{-\mathrm{a}}(\mu \mathrm{M})$ & $0.17(0.13-0.21)$ & $0.05(0.05-0.05)$ & $0.15(0.13-0.18)$ \\
\hline $\mathrm{NH}_{4}^{+\mathrm{a}}(\mu \mathrm{M})$ & $9(6-14)$ & $3(2-5)$ & $25(19-31)$ \\
\hline $\mathrm{DOC}^{\mathrm{a}}\left(\mathrm{mg} \mathrm{L}^{-1}\right)$ & $52(2-88)$ & $74(6-99)$ & $15(2-70)$ \\
\hline LOI $^{b}(\%)$ & $25(18-35)$ & $44(40-48)$ & $27(24-31)$ \\
\hline Carbon $^{b}$ (\% dry weight) & $12(10-18)$ & $20(17-24)$ & $13(11-14)$ \\
\hline $\begin{array}{l}\text { Nitrogen }{ }^{b} \\
\text { (\% dry weight) }\end{array}$ & $1.2(0.9-2.1)$ & $1.9(1.6-2.3)$ & $1.2(1.0-1.5)$ \\
\hline $\begin{array}{l}\text { Sediment grain } \\
(\text { median }-\mu \mathrm{m})\end{array}$ & $252(166-351)$ & $333(205-465)$ & 174 130-223) \\
\hline
\end{tabular}

a Characteristics of the water overlying the sediment. Ice-free season average, minimum, and maximum values. ${ }^{b}$ Characteristics of the surface sediment $(0-2 \mathrm{~cm}$ layer): Loss on ignition (LOI), as a proxy of organic matter (carbonates $<2 \%$, not shown). 


\section{Water Resources Research}

Table 2. Alternative regression models relating the DEN E $\mathrm{a}\left(\mathrm{kJ} \mathrm{mol}^{-1}\right)$ to the inverse of the nitrate concentration $\left(\left[\mathrm{NO}_{3}\right]^{-1}\right)(\mu \mathrm{M})$ in the overlying water of the lake sediments.

\begin{tabular}{|c|c|c|c|c|c|c|c|c|c|}
\hline $\begin{array}{c}\text { Regression } \\
\text { model }\end{array}$ & Random part & Formula & $\begin{array}{l}\mathbf{E}_{\mathrm{a}} \text { at nitrate } \\
\text { saturation } \\
\text { (Intercept } \pm \text { se) }\end{array}$ & p-value & Coefficient \pm se & p-value & AICc & $\begin{array}{l}\text { Fixed } \\
\mathbf{R}^{2}\end{array}$ & $\begin{array}{l}\text { Global } \\
\mathbf{R}^{2}\end{array}$ \\
\hline $\mathbf{0}$ & Lm model, no random part & $\bmod 0=\operatorname{lm}\left(\mathrm{Ea} \sim\left[\mathrm{NO}_{3}^{-}\right]^{-1}\right)$ & $50 \pm 8$ & $<0.00001$ & $315 \pm 141$ & 0.0303 & 481 & 0.09 & 0.09 \\
\hline 1 & GLS model, no random part & $\bmod 1=\operatorname{gls}\left(\mathrm{Ea} \sim\left[\mathrm{NO}_{3}^{-}\right]^{-1}\right)$ & $50 \pm 8$ & $<0.00001$ & $315 \pm 141$ & 0.0303 & 465 & 0.09 & 0.09 \\
\hline 2 & GLS model, no random part & $\begin{array}{l}\bmod 2=\operatorname{gls}\left(\mathrm{Ea} \sim\left[\mathrm{NO}_{3}^{-}\right]^{-1},\right. \\
\text { correlation=corAR1(form }=\sim \text { Add phase } \mid \text { Core }) \text { ) }\end{array}$ & $50 \pm 8$ & $<0.00001$ & $324 \pm 139$ & 0.0239 & 467 & 0.09 & 0.09 \\
\hline 3 & Sensor effect & $\bmod 3=1 \mathrm{me}\left(\mathrm{Ea} \sim\left[\mathrm{NO}_{3}^{-}\right]^{-1}\right.$, random $=\sim 1+\left[\mathrm{NO}_{3}^{-}\right]^{-1} \mid$ Sensor $)$ & $44 \pm 8$ & $<0.00001$ & $451 \pm 227$ & 0.0529 & 464 & 0.15 & 0.47 \\
\hline 4 & Sensor effect (just slope) & $\bmod 4=\operatorname{lme}\left(\mathrm{Ea} \sim\left[\mathrm{NO}_{3}^{-}\right]^{-1}\right.$, random $=\sim 0+\left[\mathrm{NO}_{3}^{-}\right]^{-1} \mid$ Sensor $)$ & $46 \pm 7$ & $<0.00001$ & $419 \pm 175$ & 0.0207 & 460 & 0.13 & 0.42 \\
\hline 5 & Sensor (with nested core effect) & $\bmod 5=\operatorname{lme}\left(\mathrm{Ea} \sim\left[\mathrm{NO}_{3}^{-}\right]^{-1}\right.$, random $=\sim 1+\left[\mathrm{NO}_{3}^{-}\right]^{-1} \mid$ Sensor $/$ Core $)$ & $45 \pm 8$ & $<0.00001$ & $438 \pm 228$ & 0.0666 & 473 & 0.14 & 0.49 \\
\hline 6 & Core effect & $\bmod 6=\operatorname{lme}\left(\mathrm{Ea} \sim\left[\mathrm{NO}_{3}^{-}\right]^{-1}\right.$, random $=\sim 1+\left[\mathrm{NO}_{3}{ }^{-}\right]^{-1} \mid$ Core $)$ & $48 \pm 9$ & $<0.00001$ & $365 \pm 177$ & 0.0505 & 469 & 0.11 & 0.34 \\
\hline 7 & Core effect (just slope) & $\bmod 7=\operatorname{lme}\left(\mathrm{Ea} \sim\left[\mathrm{NO}_{3}^{-}\right]^{-1}\right.$, random $=\sim 0+\left[\mathrm{NO}_{3}^{-}\right]^{-1} \mid$ Core $)$ & $49 \pm 8$ & $<0.00001$ & $339 \pm 153$ & 0.0368 & 465 & 0.1 & 0.29 \\
\hline 8 & Nitrate added effect & $\begin{array}{l}\bmod 8=1 \mathrm{me}\left(\mathrm{Ea} \quad \sim\left[\mathrm{NO}_{3}\right]^{-1}, \quad \text { random }=\sim 1+\left[\mathrm{NO}_{3}^{-1}\right]^{-1} \mid \text { Nitrate }\right. \\
\text { added })\end{array}$ & $42 \pm 15$ & 0.0068 & $495 \pm 298$ & 0.1038 & 472 & 0.18 & 0.3 \\
\hline 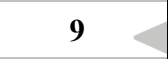 & Nitrate addition phase effect & $\bmod 9=1 \operatorname{lme}\left(\mathrm{Ea} \sim\left[\mathrm{NO}_{3}^{-}\right]^{-1}\right.$, random $=\sim 1+\left[\mathrm{NO}_{3}^{-}\right]^{-1} \mid$ Add phase $)$ & $48 \pm 10$ & $<0.00001$ & $366 \pm 200$ & 0.0732 & 472 & 0.11 & 0.15 \\
\hline 10 & Lake effect & $\bmod 10=1 \mathrm{lme}\left(\mathrm{Ea} \sim\left[\mathrm{NO}_{3}{ }^{-}\right]^{-1}\right.$, random $=\sim 1+\left[\mathrm{NO}_{3}^{-}\right]^{-1} \mid$ Lake $)$ & $50 \pm 8$ & $<0.00001$ & $315 \pm 141$ & 0.0307 & 472 & 0.09 & 0.09 \\
\hline
\end{tabular}

All the regression models have the same fixed part, that is the inverse of the nitrate concentration $\left(\left[\mathrm{NO}_{3}^{-}\right]^{-1}\right)$. Thus the models differ in the random part. The coefficient is the slope of the model and shows the influence of the inverse of nitrate concentration in the $\mathrm{E}_{\mathrm{a}}$. AICc is the second-order Akaike's information criterion for a small sample size [Mazerolle, 2016]. Fixed $\mathrm{R}^{2}$ represents the variance explained by the fixed factor $\left(\left[\mathrm{NO}_{3}\right]^{-1}\right]^{-1}$ ), and global $\mathrm{R}^{2}$ represents the total variance explained by both fixed and random factors (i.e., the entire model) [Bartoń, 2016]. Model 2 takes into account the temporal autocorrelation. Models 3, 4 and 5 take into account the sensor (\#1, \#2,\#3, \#4 or \#5) effect, thus correcting for differences in sensor performance. Models 5 (nested in the sensor), 6 and 7 consider the core (sample) effect. Model 8 takes into account the three nitrate enrichment levels, and model 9 the addition order (first, second and third). Model 10 takes into account the lake effect. Models with more than one factor crossed in the random part (not shown) were also built with the lmer function within the lme4 R package [Bates et al., 2015], these models did not improve model 1, 3 or 4 (p $(>0.05)$ in ANOVAs and showed higher AICc values). Abbreviations: $\operatorname{lm}$ (linear model), gls (linear model fitted using generalized least squares), lme (linear mixed-effects model) and se (standard error).

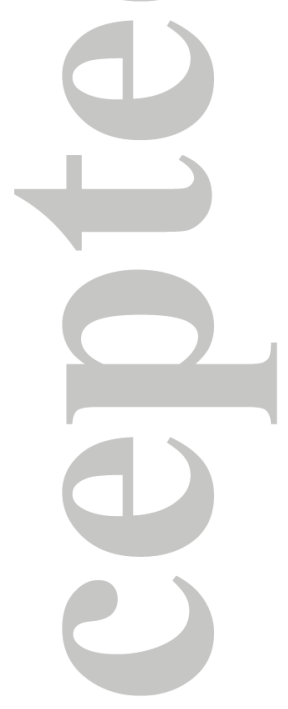


Figure 1. Main processes and aspects that affect the assessment of the denitrification temperature dependence.

Figure 2. Experimental setup. The incubation chamber ensured dark and controlled temperature $\left( \pm 1^{\circ} \mathrm{C}\right)$ conditions. Five intact lake sediment cores could be processed at once using their respective $\mathrm{N}_{2} \mathrm{O}$ sensors.

Figure 3. (a) Denitrification rates $\left(r_{d}\right)$ at the two experimental temperatures and the three nitrate enrichments. Note the natural logarithm scale in Y-axis. (b) Apparent activation energy ( $\mathrm{E}_{\mathrm{a}}$ ) at the three nitrate enrichments. The number of observations of DEN Ea was 12, 20 and 19, respectively for each level of nitrate added $(7,14$ and $28 \mu \mathrm{M})$. Note that the actual experimental nitrate concentrations in each enrichment class varied according to the initial field concentration (Table S1).

Figure 4. Denitrification temperature dependence $\left(E_{a}\right)$ against the inverse of the nitrate concentration in compiled data from aquatic ecosystems. The solid circles are data from this study. The small circles are the $E_{a}$ values resulting from each experiment $(\mathrm{N}=51)$ and the large circles correspond to the average $\mathrm{E}_{\mathrm{a}}$ values for each of the three nitrate enrichment levels. The black dotted line indicates the model $\mathrm{E}_{\mathrm{a}}=46+419\left[\mathrm{NO}_{3}\right]^{-1}$. The thin dotted lines indicate the $95 \%$ confidence intervals (see model 4 in Table 2 ). Note that $\mathrm{X}$ - and $\mathrm{Y}$-axis are on a $\log _{10}$ scale.

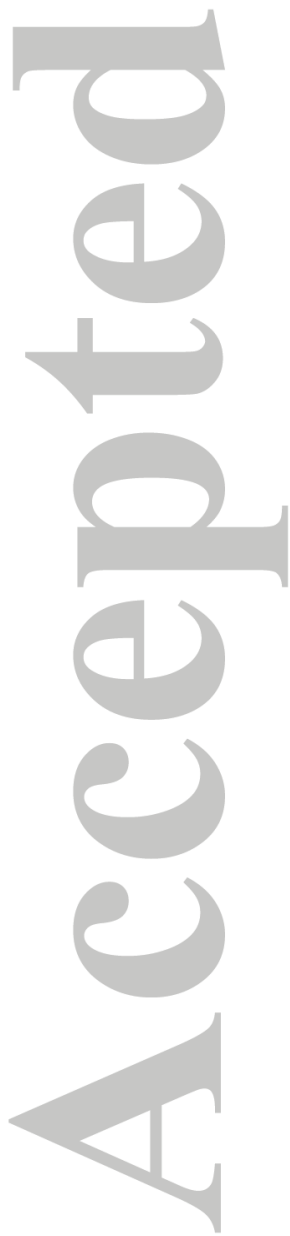




\section{Methodological approach}

Experimental control vs. observational (seasonal or spatial) inference?

Fixed anoxic conditions?
Substrate influence

Electron acceptor (e.g. nitrate)?

Electron donor (e.g. organic C)?

\section{Parameter domain}

Resource saturation vs. natural gradient?

Temperature range?
Denitrification temperature dependence analysis (DEN E $\mathrm{a}_{\mathrm{a}}$ )

\begin{tabular}{|l|}
\hline \multicolumn{2}{|c|}{ Parameter domain } \\
\hline Resource saturation vs. natural gradient? \\
Temperature range?
\end{tabular}

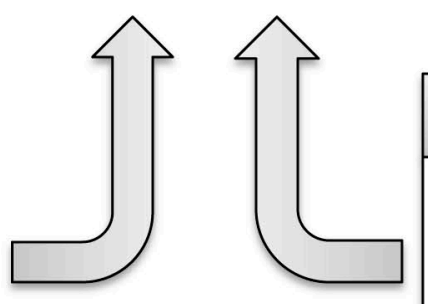

Confounding processes

DNRA nitrate competition?

Anammox nitrite competition?

Abiatic $\mathrm{N}_{2} \mathrm{O}$ production? 


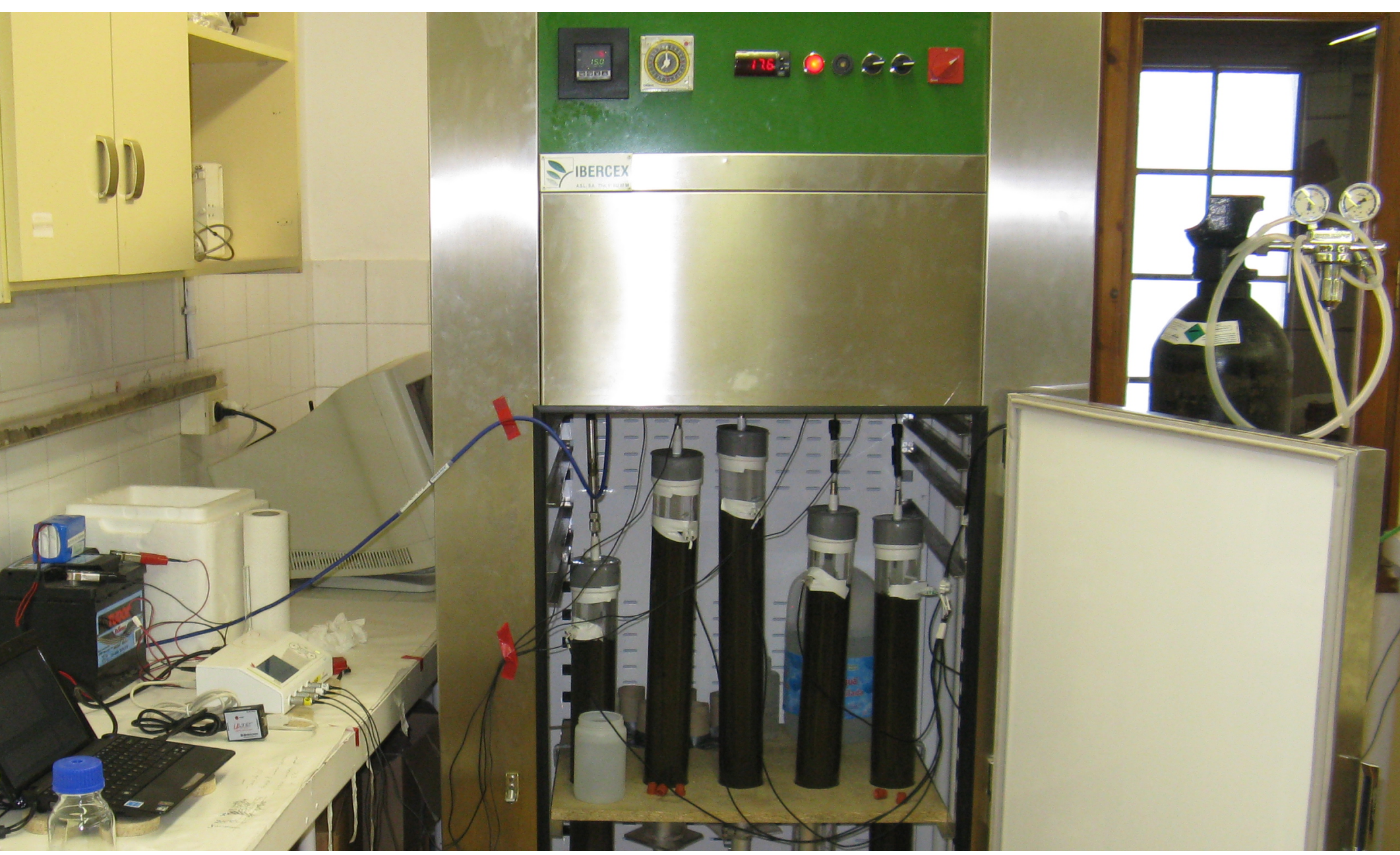


(a) Temp. $\left({ }^{\circ} \mathrm{C}\right)$

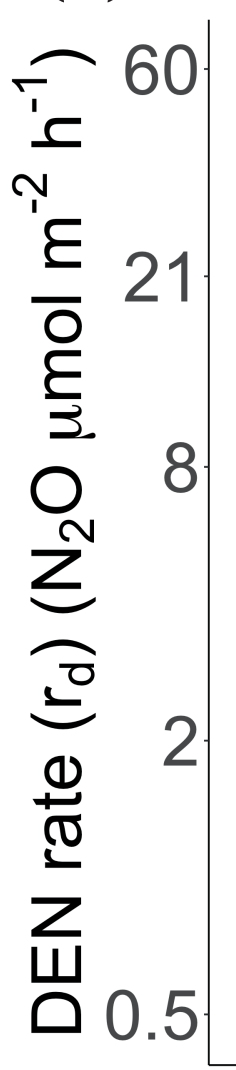

(b) $\mathrm{NO}_{3}^{-}$added $(\mu \mathrm{M})$

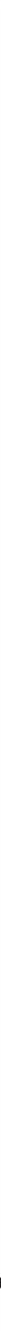




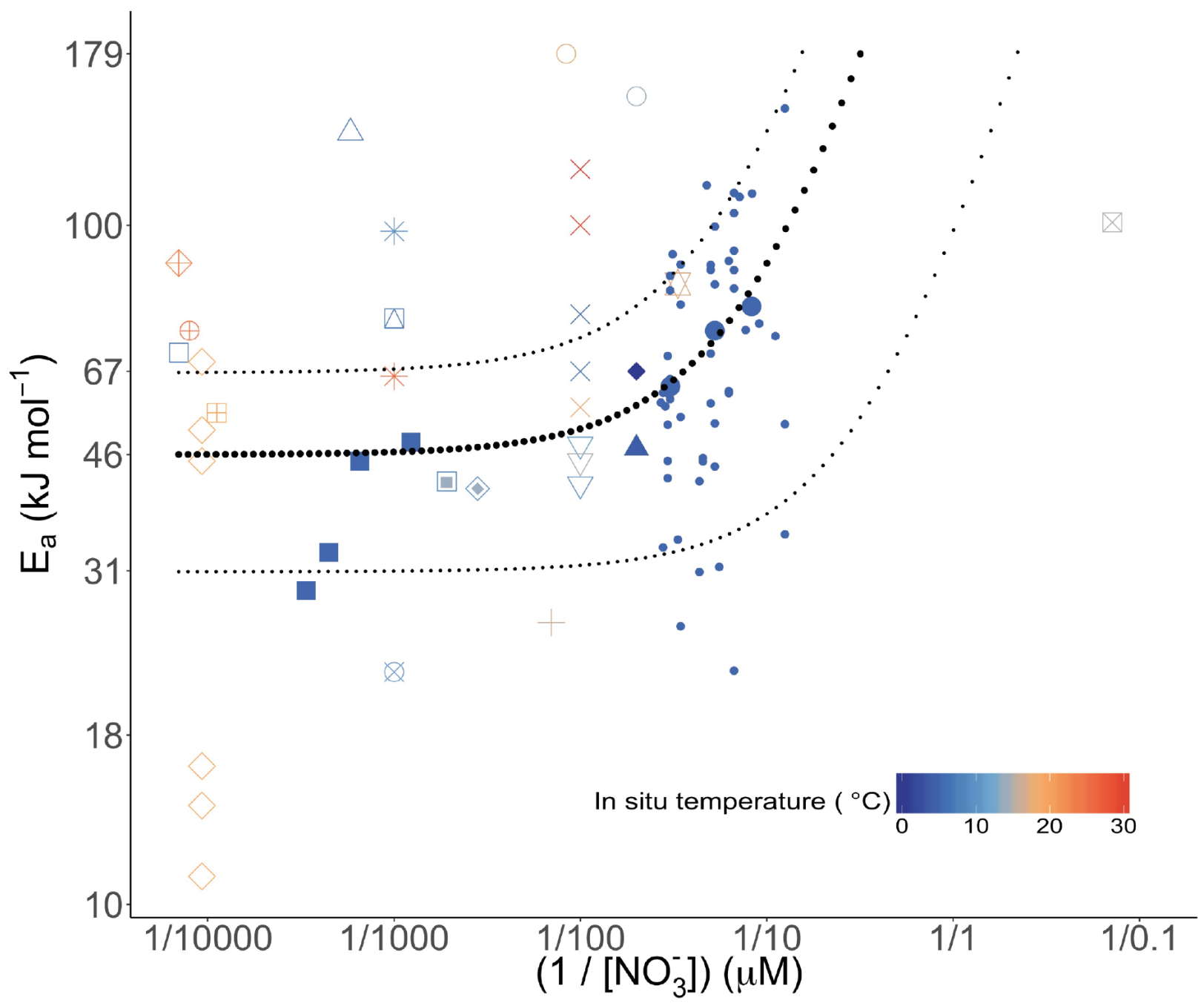

\section{Reference}

This study (Mean Ea)

- This study

•...This study (predicted Ea)

$\square$ Ambus (1993)

$\triangle$ Boulêtreau et al. (2012)

$\nabla$ Brin et al. (2017)

$\diamond$ Cameron \& Schipper (2010)

$X$ Canion et al. (2014)

- Cavari \& Phelps (1977)

$\diamond$ Holmes et al. (1996)

- Jorgensen et al. (2009)

* King \& Nedwell (1984)

Kraft et al. (2014)

$\bigoplus$ Messer \& Brezoniz (1984)

A Myrstener et al. (2016)

Pattinson et al. (1998)

$\diamond$ Pfenning \& McMahon (1996)

- Rysgaard et al. (2004)

$\bigotimes$ Sheibley et al. (2003)

Dilvennoinen et al. (2008)

$\checkmark$ Veraart et al. (2011)

$\boxplus$ Warneke et al. (2011)

$\triangle$ Westermann \& Ahring (1987) 